\title{
TRINUCLEAR SILVER(I) COMPLEX \\ OF NON-STEROIDAL ANTI-INFLAMMATORY DRUG NAPROXEN: SYNTHESIS, CHARACTERIZATION, AND IN VITRO CYTOTOXICITY
}

\author{
Sema Caglar ${ }^{*}$, Ahmet Altay ${ }^{1}$, Betül Harurluoğlu², Bulent Caglar ${ }^{1}$ \\ ${ }^{1}$ Department of Chemistry, Faculty of Arts and Sciences, Erzincan Binali Ylldırtm University, \\ 24100 Erzincan, Turkey \\ ${ }^{2}$ Department of Chemistry, Institute of Science and Technology, Erzincan Binali Yıldırım University, \\ 24100, Erzincan, Turkey \\ semacaglar2002@hotmail.com
}

\begin{abstract}
Herein, a new silver(I) complex with the non-steroidal anti-inflammatory drug naproxen and nitrogen donor 3-picoline ligands was synthesized, characterized, and subsequently tested for its cytotoxicity against different types of cancer cell lines. Elemental analysis, Fourier transform infrared spectroscopy, thermal, and proton nuclear magnetic resonance techniques showed that the molecular formula of the prepared complex is bis(3-picoline)tris( $\mu$-naproxenato)trisilver(I) and naproxen ligands bind to silver ions in a bridging bidentate mode. 2,3-bis-(2-methoxy-4-nitro-5-sulfophenyl)-2 $\mathrm{H}$-tetrazolium-5-carboxanilide (XTT) results revealed that silver salts and naproxen alone showed quite weak cytotoxic activity against human breast adenocarcinoma (MDA-MB-453), lung adenocarcinoma (A-549), and colorectal adenocarcinoma (HT-29) cell lines $\left(\mathrm{IC}_{50}>250 \mu \mathrm{M}\right.$ ), whereas the complex displayed dose dependent cytotoxicity against the aforementioned cell lines. The highest cytotoxicity was observed on MDA-MB-453 cells with an $\mathrm{IC}_{50}$ value of $11.73 \mu \mathrm{M}$. Moreover, the complex showed higher selectivity against the cancer cell lines compared to fibroblast 3T3-L1 cells. This study provides preliminary scientific data on the complex for further elucidation of its anticancer mechanism of action.
\end{abstract}

Keywords: silver(I) complex; naproxen; 3-picoline; cytotoxicity; cell culture

\section{ТРИНУКЛЕАРЕН КОМПЛЕКС НА СРЕБРО(I) НА НЕСТЕРОИДНИОТ АНТИИНФЛАМАТОРЕН ЛЕК НАПРОКСЕН: СИНТЕЗА, КАРАКТЕРИЗАЦИЈА И IN VITRO ЦИТОТОКСИЧНОСТ}

\footnotetext{
Извршена е синтеза, карактеризација, а потоа и тестирање на цитотоксичноста во однос на различни клетки на рак на нов комплекс на сребро(I) со нестероидниот антиинфламаторен лек напроксен и лиганди на азотен донор 3-пиколин. Елементната анализа, Фуриеовата трансформна инфрацрвена спектроскопија, термички и протонските нуклеарно-магнетни резонатни техники покажаа дека молекулската формула на приготвениот комплекс е бис(3-пиколин)трис( $\mu$ напроксенато)трисребро(I) и дека лигандите на напроксен се сврзани со јоните на сребро на бидентатен начин на премостување. Резултатите со 2,3-бис-(2-метокси-4-нитро-5-сулфофенил)$2 \mathrm{H}$-тетразолиум-5-карбосканилид (ХTT) покажаа дека солите на сребро и чист напроксен имаат многу слаба цитотоксична активност $\left(\mathrm{IC}_{50}>250 \mu \mathrm{M}\right)$ спрема клетки на аденокарцином на дојка (MDA-MB-453), на аденокарцином на бели дробови (А-549) и на колоректален аденокарцином (НТ-29), додека комплексот покажува цитотоксичност зависна од дозата во однос на наведените клетки. Највисока цитотоксичност е забележана врз клетки на MDA-MB-453 со вредност на $\mathrm{IC}_{50}$ од $11,73 \mu \mathrm{M}$. Покрај тоа, комплексот покажува повисока селективност во однос на клетките на рак споредено со клетките на фибробласт 3T3-L1. Ова истражување дава прелиминарни научни податоци за понатамошно разјаснување на дејството на антиканцероген механизам на комплексот.
} 
Клучни зборови: комплекс на сребро(I); напроксен; 3-пиколин; цитотоксичност; клеточна култура

\section{INTRODUCTION}

Cancer, a very important health problem has significant morbidity, treatment costs, and mortality for patients. In order to treat this disease, cisplatin and platinum-based drugs have been developed and greatly used as anticancer agents in chemotherapy $[1,2]$. However, the generation of serious side effects, toxicity for non-cancer cells, and high resistance limit their effective and successful applications in chemotherapy [3, 4]. Therefore, many research groups have focused on the synthesis and development of new metal complexes as antiproliferative agents that are more effective and have fewer side effects for curing tumors [5-10]. Silver-based complexes, which are good antiproliferative agents against many types of cancer cells, have been widely synthesized for examining their in vitro and in vivo anti-proliferative activities and comparing them with cisplatin and other platinum-based drugs [11-13].

Non-steroidal anti-inflammatory drugs (NSAIDs), which are commonly used as antipyretic, analgesic, and anti-inflammatory agents as well as for the treatment of neurodegenerative diseases (Alzheimer's) and asthma, possess seven main classes, including anthranilic acids, phenylalkanoic acids, salicylate derivates, oxicams, propanamide, sulphonamides, and furanones [14-19]. NSAIDs have also been stated to strengthen the synergistic effect of the efficiency of specific anticancer drugs, leading to the death of cancer cells via apoptosis or other mechanisms [20, 21]. Furthermore, literature studies revealed that metal-NSAID complexes have various unique biological properties, such as antiproliferative, antimicrobial, antioxidant, and DNAalbumin binding features, compared to the free NSAIDs and exhibit a significant decrease in gastrointestinal toxicity and various side effects [22-24].

Naproxen (Hnap), a prominent member of NSAIDs, has been mainly used in the treatment of headaches and fevers based on its analgesic and antipyretic features [25-28]. There are several papers in which silver-naproxen complexes are synthesized and their biological properties evaluated, showing better biological activities than naproxen [29-32]. The synthesis of novel silver(I)-naproxen complexes means designing of a new chemotherapeutic agent, and therefore, significant efforts should be made to synthesize the complexes and investigate their cytotoxic activity against both different types of cancer cell lines and normal cells.

In the present study, a novel silver(I) complex with the non-steroidal anti-inflammatory drug naproxen and nitrogen donor 3-picoline (3-pic) ligands was synthesized, and then its structural and thermal properties were investigated by Fouriertransform infrared spectroscopy (FTIR), proton nuclear magnetic resonance spectroscopy ( $\left.{ }^{1} \mathrm{H} \mathrm{NMR}\right)$, elemental, thermogravimetric analysis (TG), derivative thermogravimetric analysis (DTG), and differential thermal analysis (DTA) techniques. Afterwards, the cytotoxic activity of the complex together with the silver salts and naproxen alone was tested against the different types of cancer and normal cell lines.

\section{EXPERIMENTAL}

\subsection{Materials and methods}

$\mathrm{AgNO}_{3}$, naproxen, 3-picoline, methanol, and acetonitrile were purchased from Sigma Aldrich chemicals and used without further purification. The chemical structures of naproxen and 3-picoline are shown in Fig. 1. The Fourier transform infrared spectrum of the complex was recorded on a Thermo Nicolet 6700 spectrophotometer in the region of $4000-400 \mathrm{~cm}^{-1}$ at a resolution of $4 \mathrm{~cm}^{-1}$ using the $\mathrm{KBr}$ pellet technique. Elemental analysis was performed utilizing a LECO CHNS-932 apparatus. TG/DTG/DTA analyses runs were carried out on a PRIS Diamond TG/DTG apparatus under a dynamic air atmosphere (temperature range: $30-1000{ }^{\circ} \mathrm{C}$; heating rate: $\left.10{ }^{\circ} \mathrm{C} \mathrm{min}^{-1}\right)$. The ${ }^{1} \mathrm{H}$ NMR spectrum of the complex was obtained at room temperature on an Agilent-VNMRS-400 spectrometer operating at $400 \mathrm{MHz}$ utilizing DMSO- $\mathrm{d}_{6}$ as the solvent.

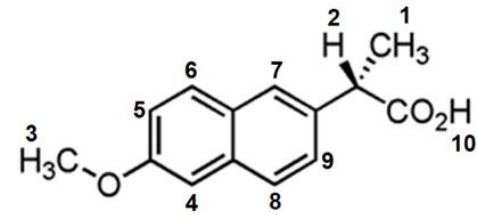

(a)<smiles>Cc1cccnc1</smiles>

(b)
Fig. 1. Molecular structure of (a) naproxen and (b) 3-picoline 


\subsection{Procedure for the synthesis of bis(3- picoline)tris( $\mu$-naproxenato)trisilver(I)}

A methanol solution $(10 \mathrm{ml})$ of naproxen (Hnap, $1 \mathrm{mmol}$ ) and $\mathrm{KOH}$ (1 mmol) was stirred for 1 $\mathrm{h}$ at $50{ }^{\circ} \mathrm{C}$. The resulting clear solution and 3-picoline (3-pic, $1 \mathrm{mmol}$ ) were added drop by drop to a stirred solution of $\mathrm{AgNO}_{3}(1 \mathrm{mmol})$ in water $(10 \mathrm{ml})$. The addition of $10 \mathrm{ml}$ of acetonitrile to the suspension resulted in a clear solution. The resulting clear solution was kept in the dark at room temperature. After one month, colourless microcrystals of bis(3picoline)tris $\left(\mu\right.$-naproxenato)trisilver(I), $\left[\mathrm{Ag}_{3}(\mu \text {-nap })_{3}\right.$ (3-pic) $)_{2}$, were acquired and kept for the analyses.

\subsection{Chemical and elemental analyses}

Colourless microcrystal product of $\left[\mathrm{Ag}_{3}(\mu-\right.$ nap $\left.)_{3}(3 \text {-pic })_{2}\right] \quad(80 \%)$ : Analytical data for $\left[\mathrm{C}_{54} \mathrm{H}_{56} \mathrm{~N}_{2} \mathrm{O}_{9} \mathrm{Ag}_{3}\right]$ :(Found: $\mathrm{C}, 54.01 \%$; H, $4.66 \%$; N, $2.35 \%$; calcd: C, $54.02 \%$; H, $4.67 \%$; N, $2.33 \%$ ).

${ }^{1} \mathrm{H}$ NMR (400 MHz, DMSO- $\left.d_{6}\right)(\delta / \mathrm{ppm})$ : 1.45 (9H, d, $\mathrm{H}^{1}$-nap), 2.28 (6H, s, $\mathrm{H}^{5}$-3-pic), 3.74 (3H, q, $\mathrm{H}^{2}$-nap), 3.85 (9H, s, $\mathrm{H}^{3}$-nap), 7.10 (3H, dd, $\mathrm{H}^{4}$-nap), $7.25\left(3 \mathrm{H}, \mathrm{d}, \mathrm{H}^{5}\right.$-nap), $7.31\left(2 \mathrm{H}, \mathrm{t}, \mathrm{H}^{3}-3-\right.$ pic), 7.45 (3H, d, $\mathrm{H}^{9}$-nap), 7.64 (2H, d, $\mathrm{H}^{4}-3$-pic), 7.75-7.68 (9H, m, $\mathrm{H}^{6}$-nap, $\mathrm{H}^{7}$-nap and $\mathrm{H}^{8}$-nap), 8.36 (2H, d, $\mathrm{H}^{2}-3$-pic), 8.41 (2H, s, $\mathrm{H}^{1}-3$-pic).

\subsection{Cell culture}

The human breast (MDA-MB-453), lung (A-549), colon (HT-29), and mouse healthy (3T3L1) cell lines were obtained from the American Type Culture Collection (ATCC, USA). MDAMB-453 cells were grown in the medium Leibovitz's L-15. A-549 cells were grown in F-12K medium. HT-29 cells were grown in McCoy's 5a medium. 3T3-L1 cells were grown in Eagle's Minimum Essential Medium. All mediums were supplemented with fetal bovine serum (10\%). The studies were performed in a Class-II biosafety cabinet (Bilser, Turkey), and incubations were done in a $\mathrm{CO}_{2}$ incubator $(5 \%)$ at $37{ }^{\circ} \mathrm{C}$ (Nuve, Turkey).

\subsection{Cytotoxicity assay}

The cytotoxicity tests were performed with the 2,3-bis-(2-methoxy-4-nitro-5-sulfophenyl)- $2 \mathrm{H}$ tetrazolium-5-carboxanilide (XTT) assay following the manufacturer's instructions (BI, Israil). Accordingly, $5 \times 10^{3}$ cells (for each cell line) were seeded in 96-well plates and incubated in a $\mathrm{CO}_{2}$ incubator overnight. The next day, all the cancerous cells were treated with the different concentrations (1$100 \mu \mathrm{M}$ ) of the metal complex, ligand (naproxen), and silver alone, whereas healthy cells were treated with only the metal complex $(1-250 \mu \mathrm{M})$. After incubation for $24 \mathrm{~h}$, the absorbance was measured at $490 \mathrm{~nm}$ using an Elisa plate reader (BioTek, USA). Untreated cells were used as a negative control, and carboplatin was evaluated as a positive control. The cytotoxicity results were represented as half-maximal inhibitory concentration $\left(\mathrm{IC}_{50}\right)$ values, plotted from the dose-response versus percent cell cytotoxicity curve using Graph Pad Prism 6 . The Selectivity Index (SI) was determined as the ratio of the $\mathrm{IC}_{50}$ value of the complex on the normal cell line to the $\mathrm{IC}_{50}$ value on the cancer cell line. The percent cytotoxicity was calculated using the following formula: \% Cell cytotoxicity $=[1-$ $\mathrm{Abs}($ drug)$/ \mathrm{Abs}$ (control) $] \times 100$.

\subsection{Statistical analysis}

Statistical analyses were carried out by one way analysis of variance (ANOVA) with unpaired $t$-test using the statistical program GraphPad Prism 6 (GraphPad, La Jolla, CA) Software 7.0. All results were represented with their standard error of the mean (SEM) values. Statistical differences between two groups were calculated using Student's $t$-test. $p<0.05$ was considered significant.

\section{RESULTS AND DISCUSSION}

\subsection{Thermal analyses}

The TG/DTG/DTA curves for the $\left[\mathrm{Ag}_{3}(\mu-\right.$ nap) $)_{3}(3 \text {-pic })_{2}$ ] complex demonstrate two weight loss steps (Fig. 2). The first step of extrication occurs within the range of $30-216^{\circ} \mathrm{C}$ with the maxima at $95(+){ }^{\circ} \mathrm{C}, 146(+){ }^{\circ} \mathrm{C}$ and corresponds to the loss of two 3-pic molecules with an estimated mass loss of $15.27 \%$ (calc. mass loss of $15.53 \%$ ). The DTG curve gives the peaks at $119^{\circ} \mathrm{C}$. The second step can be attributed to the loss of three nap molecules within the range of $216-502{ }^{\circ} \mathrm{C}$, with the maxima at 217(+), 273(-), 231(+), and $414(-){ }^{\circ} \mathrm{C}$ and an estimated mass loss of $59.27 \%$ (calc. mass loss of $57.47 \%$ ). The DTG curve gives the peaks at $204,231,259$, and $414{ }^{\circ} \mathrm{C}$. At the end of the thermogram, the metallic silver is the residue, which is in good agreement with the calculated metallic silver (estimated mass loss of $25.46 \%$; calc. mass loss of $27.00 \%$ ). 


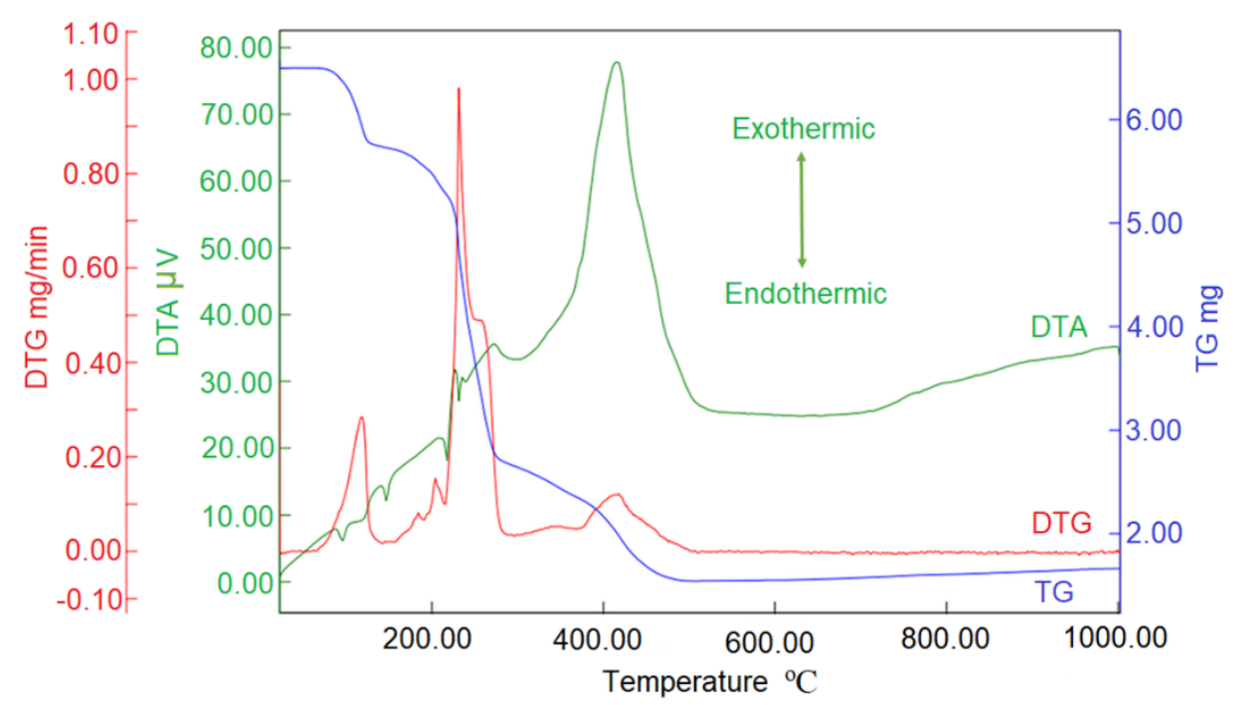

Fig. 2. The thermogravimetric analysis (TG), derivative thermogravimetric analysis (DTG), and differential thermal analysis (DTA) curves of $\left[\mathrm{Ag}_{3}(\mu-\text { nap })_{3}(3-\text { pic })_{2}\right]$

\subsection{Fourier transform infrared analyses}

The FTIR spectrum of $\left[\mathrm{Ag}_{3}(\mu \text {-nap })_{3}(3 \text {-pic })_{2}\right]$ is shown in Figure 3. The broad functional group region of the FT-IR spectrum of naproxen is due to the carboxylic $v(\mathrm{O}-\mathrm{H})$ stretching vibration band at $3250 \mathrm{~cm}^{-1}$, whereas this width disappeared from the functional group region of $\left[\mathrm{Ag}_{3}(\mu-n a p)_{3}(3-\right.$ pic) $)_{2}$ ] because of the deprotonation of naproxen. This event indicates that the coordination takes places through the carboxylic group in the complex. The carboxylic $v(\mathrm{COOH})$ stretching vibration observed in naproxen at $1728 \mathrm{~cm}^{-1}$ turns into asymmetric and symmetric stretching vibrations with a complex formation at $1537 \mathrm{~cm}^{-1}$ and 1378 $\mathrm{cm}^{-1}$, respectively. By making use of the difference between asymmetric $\left(\mathrm{COO}^{-}\right)$and symmetric $\left(\mathrm{COO}^{-}\right)$ stretching vibrations, comments can be made about the bonding of the carboxylic group to the silver(I) ion [33]. The $\Delta v$ value was determined to be 159 $\mathrm{cm}^{-1}$; this value is consistent with the bridging bidentate mode. The aromatic and aliphatic $v(\mathrm{CH})$ stretching band of naproxen and 3-pic arises between 3062 and $2936 \mathrm{~cm}^{-1}$. The $v(\mathrm{C}=\mathrm{C})$ and $v(\mathrm{C}=\mathrm{N})$ stretching vibrations of rings arises at 1602 , 1575,1479 , and $1461 \mathrm{~cm}^{-1}$. The medium intensity band at $1210 \mathrm{~cm}^{-1}$ may be appointed to the $v(\mathrm{C}-\mathrm{O}-$ C) asymmetric stretching, while the weak bands at around $1029 \mathrm{~cm}^{-1}$ are assigned to the $v(\mathrm{C}-\mathrm{O}-\mathrm{C})$ symmetric stretching of the naproxen ligand.

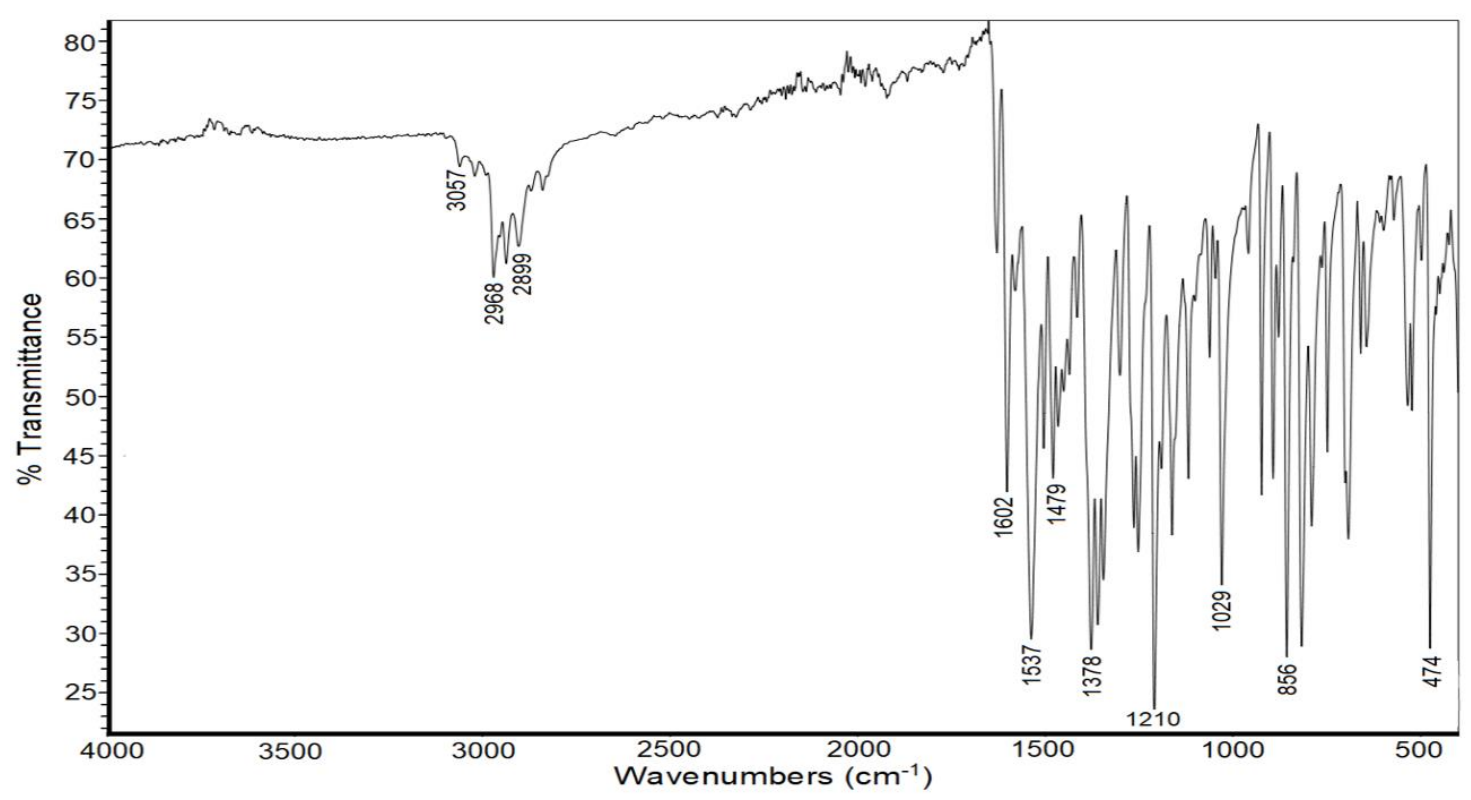

Fig. 3. The Fourier transform infrared spectrum of $\left[\mathrm{Ag}_{3}(\mu-\text { nap })_{3}(3-\text { pic })_{2}\right]$ 


\subsection{Proton nuclear magnetic resonance spectroscopy studies}

The ${ }^{1} \mathrm{H}$ NMR spectrum of the silver(I) complex was obtained using DMSO- $\mathrm{d}_{6}$ as a solvent (Fig. 4). The appearance of the ${ }^{1} \mathrm{H}$ NMR peaks belonging to naproxen and 3-picoline in the synthesized silver(I) complex also confirms the formation of the structure. The ${ }^{1} \mathrm{H}$ NMR spectrum of the $\left[\mathrm{Ag}_{3}(\mu \text {-nap })_{3}(3 \text {-pic })_{2}\right]$ complex demonstrates singlet signals at 1.45 and $2.28 \mathrm{ppm}$, which are attributed to the proton of the methyl group of naproxen and 3-picoline, respectively. The methoxy $\left(-\mathrm{OCH}_{3}\right)$ proton peak of naproxen appears as a singlet at $3.85 \mathrm{ppm}$. The ${ }^{1} \mathrm{H}$ NMR spectrum of the $\left[\mathrm{Ag}_{3}(\mu \text {-nap })_{3}(3 \text {-pic })_{2}\right]$ complex showed all aromatic protons as multiple peaks in the region from 7.10 to $8.41 \mathrm{ppm}$ arising from naproxen and 3-picoline. The spectrum of naproxen demonstrated the signal of the carboxylic $-\mathrm{OH}$ proton at $11.00 \mathrm{ppm}$; this peak vanished in the spectrum of $\left[\mathrm{Ag}_{3}(\mu \text {-nap })_{3}(3-\right.$ pic $)_{2}$, displaying the coordination of naproxen to the silver(I) ion via the carboxylic group. The extinction and slightly shifted downfield or upfield of these proton peaks show the coordination of the ligands to the silver(I) ions. From the number of protons that emerged in the ${ }^{1} \mathrm{H}$ NMR spectrum of $\left[\mathrm{Ag}_{3}(\mu \text {-nap) })_{3}(3 \text {-pic })_{2}\right]$, we can deduce that the ratio of nap:3-pic is $3: 2$. The ${ }^{1} \mathrm{H}$ NMR data clearly demonstrate both the purity and presence of the structure.

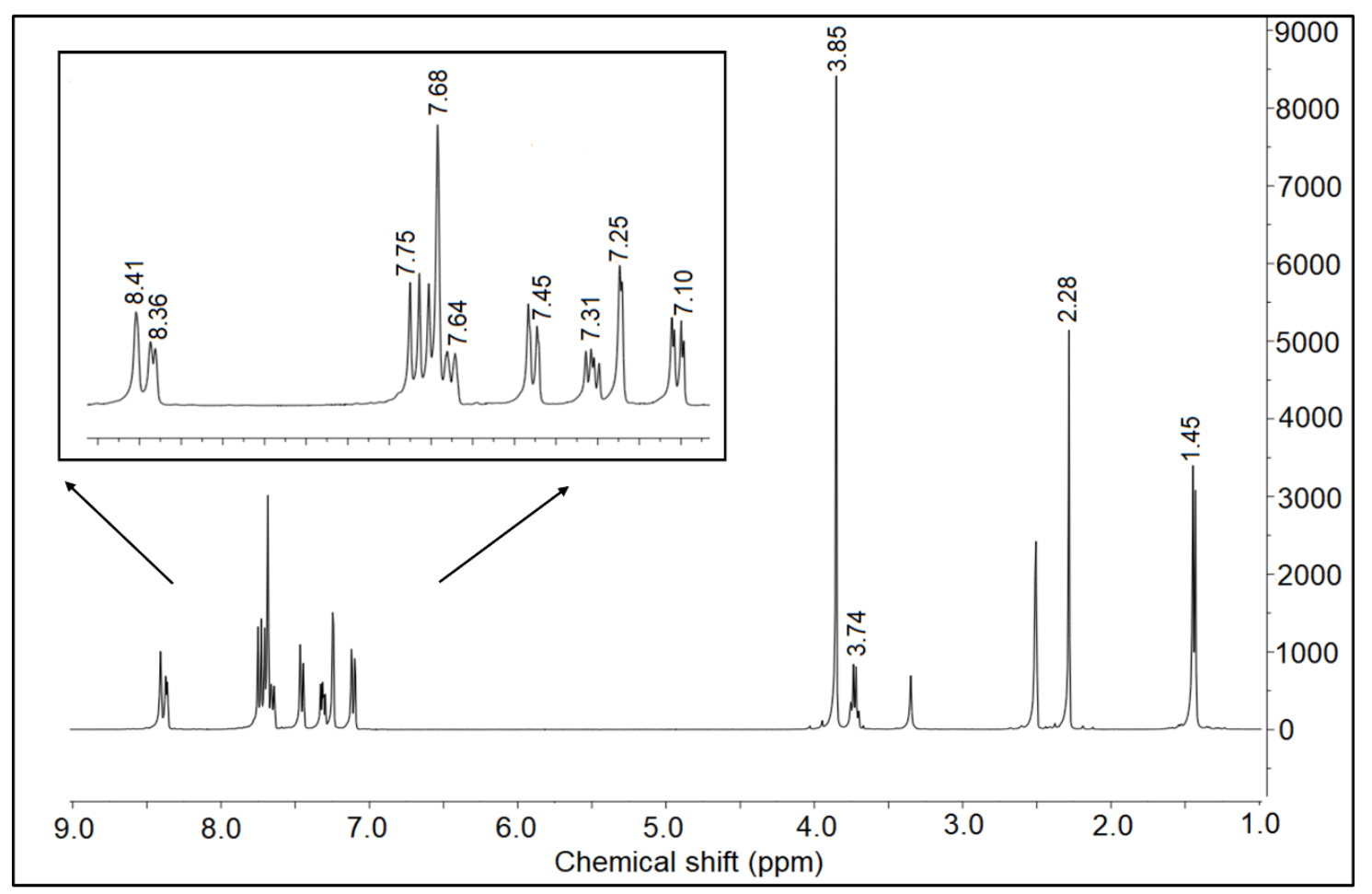

Fig. 4. Proton nuclear magnetic resonance spectrum of $\left[\mathrm{Ag}_{3}(\mu \text {-nap })_{3}(3-\mathrm{pic})_{2}\right]$

\subsection{Proposed structure}

Based on the thermal and elemental analyses data, $\left[\mathrm{Ag}_{3}(\mu \text {-nap })_{3}(3 \text {-pic })_{2}\right]$ is a neutral trinuclear complex. According to the FTIR spectrum data, the naproxenato ligands are deprotonated and anticipated to be bound to silver ions in a bridging bidentate mode through carboxylate oxygen atoms. 3-picoline ligands are bound to silver ions via a nitrogen atom. Additionally, based on the ${ }^{1} \mathrm{H}$ NMR data, $\left[\mathrm{Ag}_{3}(\mu \text {-nap })_{3}(3 \text {-pic })_{2}\right]$ complex has a $3: 2$ (nap:3-pic) stoichiometric ratio around the silver(I) ions.

\subsection{Cytotoxicity}

In the present study, the cytotoxicity of the novel $\operatorname{Ag}(\mathrm{I})$ complex with naproxen belonging to NSAIDs was tested against the carcinogenic (MDA-MB-453, A-549, and HT-29) and noncarcinogenic (3T3-L1) cell lines by the XTT assay. In addition, the toxic effects of the silver metals and naproxen alone were also tested on the aforementioned cell lines. In comparison to the nondrug-treated control, the 24-hr treatment of the cancer and non-cancerous cells with the novel $\mathrm{Ag}(\mathrm{I})$ complex ranging from 5 to $100 \mu \mathrm{M}$ resulted 
in a significant dose-dependent cytotoxicity in all the cell lines tested (Fig. 5A-D). In addition, the $\mathrm{IC}_{50}$ values of the $\mathrm{Ag}(\mathrm{I})$ complex together with the naproxen and silver metal alone were calculated, as described in the materials and methods section, and given in Table 1. Considering Table 1, the order of cytotoxic activities of the $\operatorname{Ag}(\mathrm{I})$ complex on the cancer and non-cancerous cells from the highest to lowest is as follows; MDA-MB-453 $\left(\mathrm{IC}_{50}=11.73\right.$ $\mu \mathrm{M})>\mathrm{A}-549 \quad\left(\mathrm{IC}_{50}=40.38 \mu \mathrm{M}\right)>\quad$ HT-29 $\left(\mathrm{IC}_{50}=69.33 \mu \mathrm{M}\right)>3 \mathrm{~T} 3-\mathrm{L} 1(133.36 \mu \mathrm{M})$. These results indicate that of the cancer cells tested, MDA-
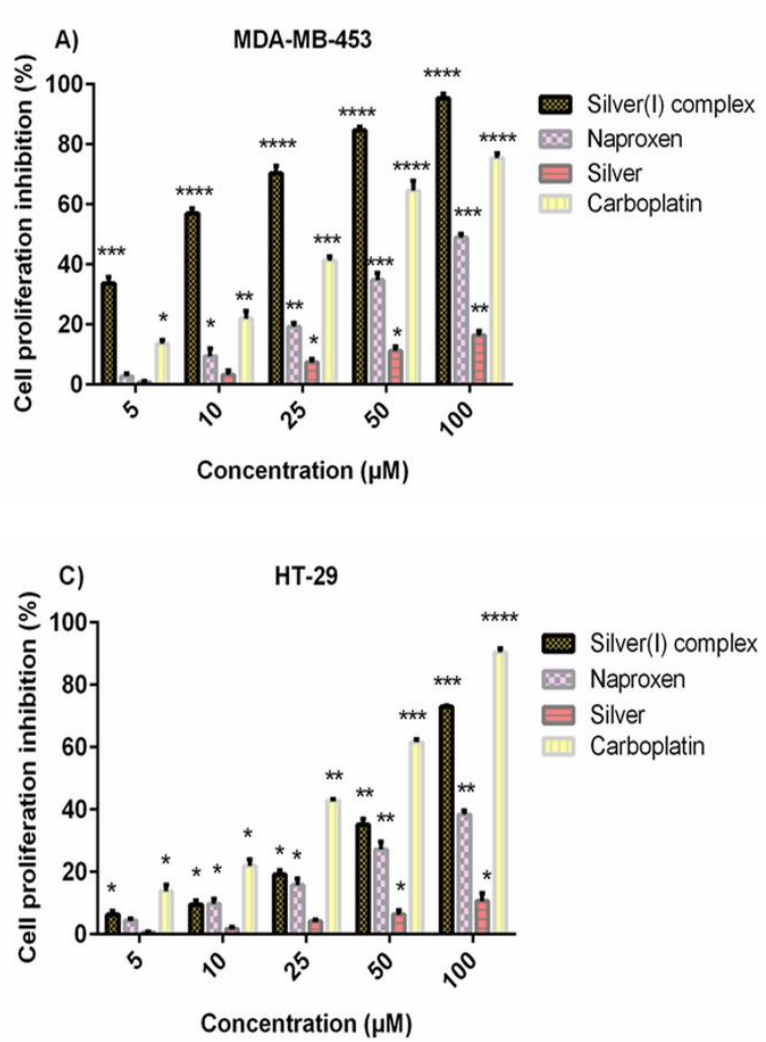

MB-453 cells were the most sensitive to the cytotoxic activity of the $\operatorname{Ag}(\mathrm{I})$ complex, whereas HT-29 cells were the most resistant. Moreover, these data reveal the fact that the complex produced lower toxicity on the healthy cell line compared to the cancerous cell lines. As seen in Table 1 and Fig. 5, compared to the chemotherapeutic drug carboplatin commonly used in cancer treatment, the complex exhibited stronger cytotoxicity than this drug against MDA-MB-453 cells $(* * * p<0.005)$, similar activity on A-549 cells $(p>0.05)$, and moderately lower activity on HT-29 cells $(* * p<0.01)$.
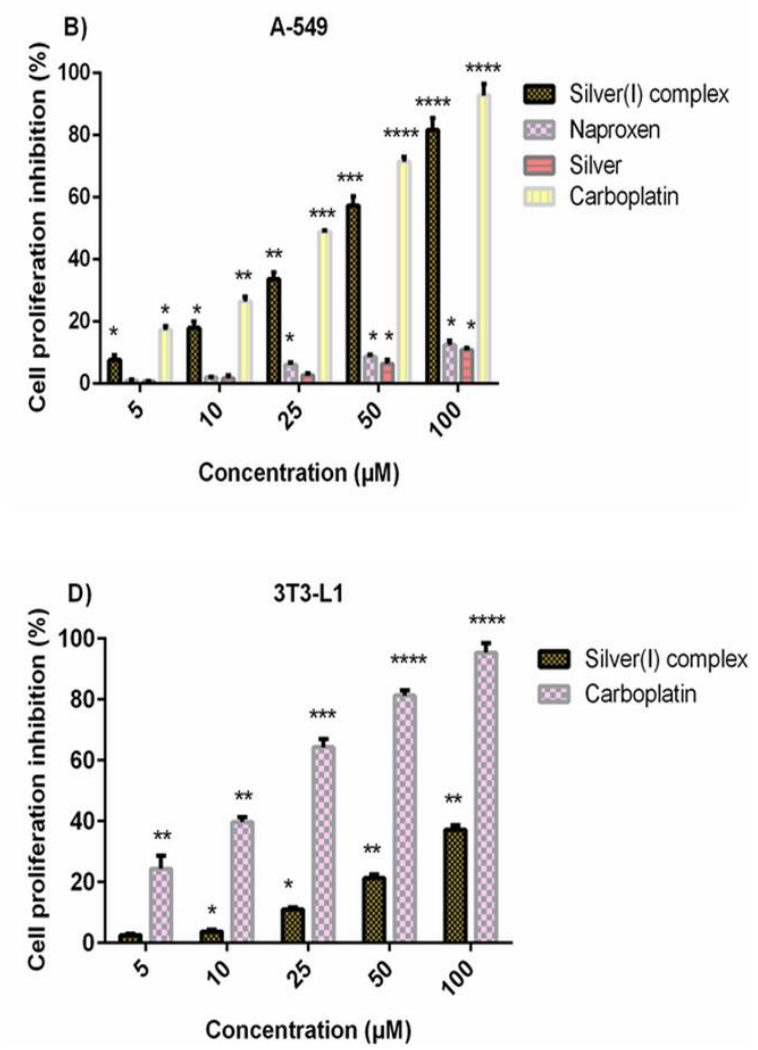

Fig. 5. Dose dependent cytotoxic activities of the silver(I) complex, silver, naproxen, and carboplatin against human breast adenocarcinoma (MDA-MB-453) cells (a), lung adenocarcinoma (A-549) cells (b), colorectal adenocarcinoma (HT-29) cells (c), and non-carcinogenic mouse fibroblast (3T3-L1) cells (d). The differences in the data between the control (non-treated) and sample-treated cells were evaluated by Student's $t$-test. $* p<0.05 ; * * p<0.01 ; * * *<0.005 ; * * * *<0.0001$.

One of the most crucial points of this study was the comparison of the selectivity of the $\operatorname{Ag}(\mathrm{I})$ complex and carboplatin tested between the cancer and healthy cell lines. As seen in Table 1, the selectivity of the $\operatorname{Ag}(\mathrm{I})$ complex on cancer cell lines in order from the highest to lowest is as follows: MDA-MB-453 $(\mathrm{SI}=11.36)>\mathrm{A}-549(\mathrm{SI}=3.30)>$ HT-29 (SI = 1.92). These data suggest that the $\mathrm{Ag}(\mathrm{I})$ complex exhibits stronger cytotoxicity with higher selectivity on cancer cells compared to healthy cells. Moreover, the $\mathrm{Ag}(\mathrm{I})$ complex exhibits higher selectivity on all 3 cancer cell lines com- pared to carboplatin, with SI values of $0.47,0.63$, and 0.53 on MDA-MB-453, A-549, and HT-29 cell lines, respectively.

When the effects of the silver in the structure of the complex and naproxen, one of the NSAID groups, are examined, it is seen that silver metals have very low cytotoxic activity on all the cancer cell lines (Fig. 5). It was also determined that the $\mathrm{IC}_{50}$ values of the metals alone on the tested cell lines were above $250 \mu \mathrm{M}$. On the other hand, naproxen showed moderate cytotoxicity in a dose-dependent manner on the cancer and healthy 
cell lines when tested alone (Fig. 5A-D). As seen in Table 1, naproxen exhibited a moderately low level of cytotoxicity on MDA-MB-453 $\left(\mathrm{IC}_{50}=96.22 \mu \mathrm{M}\right)$ and $\mathrm{HT}-29\left(\mathrm{IC}_{50}=123.24 \mu \mathrm{M}\right)$ cell lines compared to the $\operatorname{Ag}(\mathrm{I})$ complex, while a very low level of cytotoxic activity on A-549 $\left(\mathrm{IC}_{50}=250 \mu \mathrm{M}\right)$ and 3T3-L1 $\left(\mathrm{IC}_{50}=250 \mu \mathrm{M}\right)$ cell lines was observed.

Table 1

The $I C_{50}$ values of the $A g(I)$ complex, naproxen, silver, and carboplatin against both cancer and normal cell lines

\begin{tabular}{|c|c|c|c|c|}
\hline \multicolumn{5}{|c|}{ Cell lines $\mathrm{IC}_{50}(\mu \mathrm{M})^{\mathrm{x}}$} \\
\hline Test samples & MDA-MB-453 & A-549 & HT-29 & 3T3-L1 \\
\hline$\left[\mathrm{Ag}_{3}(\mu-\text { nap })_{3}(3-\text { pic })_{2}\right]$ & $11.73 \pm 0.65^{\mathrm{a}}$ & $40.38 \pm 1.25^{\mathrm{a}}$ & $69.33 \pm 2.34^{\mathbf{b}}$ & $133.36 \pm 2.10^{b}$ \\
\hline SI $(\text { complex })^{\mathrm{y}}$ & 11.36 & 3.30 & 1.92 & \\
\hline [Naproxen] & $96.22 \pm 2.56^{\mathrm{c}}$ & $250>b$ & $123.24 \pm 2.46^{c}$ & $250>c$ \\
\hline [Silver] & $250>d$ & $250>\mathbf{b}$ & $250>d$ & $250>c$ \\
\hline [Carboplatin] & $48.47 \pm 1.35^{\mathbf{b}}$ & $36.2 \pm 1.06^{\mathrm{a}}$ & $42.79 \pm 2.12^{\mathrm{a}}$ & $22.87 \pm 1.20^{a}$ \\
\hline SI $(\text { carb })^{\mathrm{y}}$ & 0.47 & 0.63 & 0.53 & \\
\hline
\end{tabular}

${ }^{x} \mathrm{IC}_{50}(\mu \mathrm{M})$ : Different superscripts (a-d) within the same column show the statistical differences.

${ }^{y}(\mathrm{SI})$ : Selectivity index for the $\mathrm{Ag}(\mathrm{I})$ complex and carboplatin.

Toxicity tests have been widely performed as a mandatory step to introduce a new chemical drug to the pharmaceutical industry [34-37]. Many researchers have synthesized numerous novel metal complexes with different metals and ligands belonging to NSAIDs and tested their cytotoxicity against different types of cancer cell lines. For instance, the cytotoxic activities of different metal complexes with mefenamic acid $\left(\left[\mathrm{Mn}(\mathrm{mef})_{2}\left(\mathrm{H}_{2} \mathrm{O}\right)_{2}\right]\right.$, [Co(mef $\left.)_{2}\left(\mathrm{H}_{2} \mathrm{O}\right)_{2}\right], \quad\left[\mathrm{Ni}(\mathrm{mef})_{2}\left(\mathrm{H}_{2} \mathrm{O}\right)_{2}\right]$, $\left[\mathrm{Cu}(\mathrm{mef})_{2}\left(\mathrm{H}_{2} \mathrm{O}\right)\right]_{2},\left[\mathrm{Cd}(\mathrm{mef})_{2}(\mathrm{MeOH})\right],\left[\mathrm{Bi}\left(\mathrm{mef}_{3}\right]\right.$, $\left[\mathrm{Zn}(\mathrm{mef})_{2}\right]$, and $\left[\mathrm{Cd}_{2}(\mathrm{dikl})_{4} 1.5(\mathrm{MeOH})_{2}\left(\mathrm{H}_{2} \mathrm{O}\right)\right]_{\mathrm{n}}$ were reported against human breast adenocarcinoma (MCF7), lung adenocarcinoma (A-549), and mouse fibroblast (L929) cell lines, and it was determined that their $\mathrm{IC}_{50}$ values ranged from 2.5 to $45 \mu \mathrm{M}$ depending on the type of metal $[38,39]$. Giovagnini et al. tested the cytotoxicity of $\mathrm{Pd}(\mathrm{II})$ and $\mathrm{Pt}(\mathrm{II})$ complexes with picoline derivatives on human squamous cervical adenocarcinoma (HeLa), colorectal adenocarcinoma (LoVo), leukemic promyelocytes (HL60), and human Burkitt lymphoma (Daudi) and determined that their $\mathrm{IC}_{50}$ values ranged from 9 to $100 \mu \mathrm{M}$ based on the cell line [40]. Moreover, in our previous studies, we tested and compared the cytotoxic activities of various $\mathrm{Ag}(\mathrm{I}), \mathrm{Co}(\mathrm{II})$, and $\mathrm{Ni}(\mathrm{II})$ complexes with different NSAIDs group, including mefenamic acid, niflumic acid, tolfenamic acid, and diclofenac together with picoline derivatives against different cancer cell lines (MCF-7, MDA-MB-453, HT-29 and HepG2) as well as a healthy cell line (3T3-L1), showing that their $\mathrm{IC}_{50}$ values varied between approximately 20 and $100 \mu \mathrm{M}$ [41-45]. Furthermore, the $\mathrm{IC}_{50}$ values of heteroleptic silver(I) complexes with naproxen on human breast adenocarcinoma (MCF-7), cervical (HeLa), epithelioma (Hep-2), and hepatoma (HepG2) cancerous cells were reported to have different values varying from 8.21 to $9.26 \mu \mathrm{M}$ [46]. In another study, the $\mathrm{IC}_{50}$ values of heteroleptic silver(I) complexes with naproxen against human breast cancer cell lines (MCF-7 and MDA-MB-231) and pancreatic (PANC-1) cell lines were stated to change between the range of 73.43 to $107.09 \mu \mathrm{M}$ depending on the cell line [47]. When these results are compared with the literature and our previous studies, we can state that the cytotoxic activity of this $\left[\mathrm{Ag}_{3}(\mu-n a p)_{3}(3-\right.$ pic) $)_{2}$ complex varies considerably depending on the cell line tested. This complex especially exhibits moderate to high cytotoxicity and better selectivity on MDA-MB-453 cells.

Undoubtedly, the cytotoxicity in different cancer cell lines is influenced by the type of NSAIDs in the tested complex. Chang et al. reported the cytotoxic potency of different NSAIDs (indomethacin, diclofenac, ketorolac, and piroxicam) alone against osteoblasts, and the results demonstrated that these NSAIDs at $100 \mu \mathrm{M}$ cause cytotoxicity on the cells ranging from $30 \%$ to $70 \%$ [48]. Erfani-Moghadam et al. reported the cytotoxic activity of naproxen alone against four different monolayer cell lines (MDA-MDB-231, MCF-7, A549, and $\mathrm{HeLa}$ ); the $\mathrm{IC}_{50}$ values on $\mathrm{A} 549$ and 
Hela cells are 3300 and $1950 \mu \mathrm{M}$, respectively, whereas it is above $4000 \mu \mathrm{M}$ on MCF-7 and MDA-MB-231 cells [49]. Considering the cytotoxic effects of silver salts alone, the data we obtained in this study are similar to the literature. Ramar et $a l$. tested the cytotoxic power of silver nanoparticles against MCF-7 cells and reported the $\mathrm{IC}_{50}$ value to be $463 \mu \mathrm{M}$ [50]. It has been reported that the $\mathrm{Ag}_{2} \mathrm{CO}_{3}$ compound does not exhibit cytotoxic activity up to $0.5 \mathrm{mg} / \mathrm{l}$ on $\mathrm{HepG} 2$ cells [51]. Moreover, the $\mathrm{IC}_{50}$ value of $\mathrm{AgNO}_{3}$ against HeLa cells was reported to be $158 \mu \mathrm{M}$ [37]. These results show that soluble silver salts like $\mathrm{AgNO}_{3}, \mathrm{Ag}_{2} \mathrm{CO}_{3}$, as well as silver nanoparticles possess a quite low cytotoxic activity against cancer and healthy cell lines. The data that we have obtained in this study together with the literature show that NSAIDs containing naproxen alone show a very low cytotoxic effect on cancer cell lines. On the other hand, as seen in the present and previous studies, NSAIDs in their complex form exhibit much stronger cytotoxicity with a higher synergistic effect.

\section{CONCLUSION}

A novel trinuclear $\operatorname{Ag}(\mathrm{I})$ complex including the naproxen and 3-picoline ligands was synthesized and characterized. The molecular formula of the complex was determined by ${ }^{1} \mathrm{H}$ NMR, elemental and thermal analysis techniques. The results from all techniques proved the existence of three naproxen ligands that are bound to a silver ion. The $\Delta v$ value derived from FTIR spectroscopy indicated a bridging bidentate coordination mode of the naproxen ligand. Two major mass loss stages occurred in the decomposition of the complex to metallic silver. As a result of the XTT tests, the newly synthesized $\operatorname{Ag}(\mathrm{I})$ complex showed the highest cytotoxic activity against MDA-MB-453 cells among the tested cancer cell lines, while the lowest activity was shown on HT-29 cells. Moreover, the complex exhibited a high selectivity between the healthy and cancer cell lines. Furthermore, despite the drug and silver salts alone that make up the complex exhibiting a very low cytotoxic activity on the cancer cells, the complex possessed a quite robust cytotoxicity with a synergistic effect. These data suggest that the novel silver(I) complex with naproxen could be a unique candidate for future in vivo anticancer application studies.

Acknowledgements. The authors are grateful to the Erzincan Binali Yıldırım University Scientific Research Projects Coordination Commission (EU-BAP) for the financial support under the Project No: FBA-2020-683.

\section{REFERENCES}

[1] B. Rosenberg, Cisplatin: Its History and Possible Mechanisms of Action, Academic Press, Inc. 1980. DOI:10.1016/b978-0-12-565050-2.50006-1.

[2] B. T. Benedetti, E. J. Peterson, P. Kabolizadeh, A. Martínez, R. Kipping, N. P. Farrell, Effects of noncovalent platinum drug-protein interactions on drug efficacy: Use of fluorescent conjugates as probes for drug metabolism, Mol. Pharm. 8, 940-948 (2011). DOI:10.1021/mp2000583.

[3] A. Bhargava, U. N. Vaishampayan, Satraplatin: Leading the new generation of oral platinum agents, Expert Opin. Investig. Drugs. 18, 1787-1797 (2009). DOI: $10.1517 / 13543780903362437$.

[4] M. Frezza, S. Hindo, D. Chen, A. Davenport, S. Schmitt, D. Tomco, Q. Ping Dou, Novel metals and metal complexes as platforms for cancer therapy, Curr. Pharm. Des. 16, 1813-1825 (2010). DOI:10.2174/138161210791209009.

[5] T. C. Karlenius, K. F. Tonissen, Thioredoxin and cancer: A role for thioredoxin in all states of tumor oxygenation, Cancers (Basel). 2, 209-232 (2010). DOI:10.3390/cancers2020209.

[6] A. Bindoli, M. Pia, G. Scutari, C. Gabbiani, A. Casini, L. Messori, Thioredoxin reductase: A target for gold compounds acting as potential anticancer drugs, Coord. Chem. Rev. 253, 1692-1707 (2009). DOI:10.1016/j.ccr.2009.02.026.

[7] A. Gupte, R. J. Mumper, Elevated copper and oxidative stress in cancer cells as a target for cancer treatment, Cancer Treat. Rev. 35, 32-46 (2009).

DOI:10.1016/j.ctrv.2008.07.004.

[8] C. Monneret, Platinum anticancer drugs. From serendipity to rational design, Ann. Pharm. Fr. 69, 286295 (2011).

DOI:10.1016/j.pharma.2011.10.001.

[9] T. C. Johnstone, K. Suntharalingam, S. J. Lippard, The next generation of platinum drugs: Targeted Pt(II) agents, Nanoparticle Delivery, and Pt(IV) prodrugs, (2016). DOI:10.1021/acs.chemrev.5b00597.

[10] Q. Mi, Y. Ma, X. Gao, R. Liu, P. Liu, Y. Mi, X. Fu, 2Deoxyglucose conjugated platinum(II) complexes for targeted therapy: design, synthesis, and antitumor activity, J. Biomol. Struct. Dyn. 1102, 2339-2350 (2016). DOI:10.1080/07391102.2015.1114972.

[11] M. Pedro, M. Mara, C. Lidia, Organometallic compounds in cancer therapy: Past lessons and future directions, Bentham Sci. Publ. 14, 1199-1214 (2014).

[12] R. A. Haque, S. Budagumpi, H. Z. Zulikha, M. B. Khadeer, A. M. S. Abdul, Silver(I)-N-heterocyclic carbene complexes of nitrile-functionalized imidazol-2ylidene ligands as anticancer agents, Inorg. Chem. Commun. 44, 128-133 (2014). DOI:10.1016/j.inoche.2014.03.016.

[13] S. Li, S. Zhang, X. Jin, X. Tan, J. Lou, X. Zhang, Y. Zhao, Singly protonated dehydronorcantharidin silver coordination polymer induces apoptosis of lung cancer cells via reactive oxygen species-mediated mitochondrial pathway, Eur. J. Med. Chem. 86, 1-11 (2014). DOI:10.1016/j.ejmech.2014.08.052. 
[14] C. N. Bantia, A. G. Hatzidimitriou, N. Kourkoumelis, S. K. Hadjikakou, Diclofenac conjugates with biocides through silver(I) ions (CoMeD's); Development of a reliable model for the prediction of anti-proliferation of NSAID's-silver formulations, J. Inorg. Biochem, 194, 7-18 (2019). DOI: https:// doi.org/10.1016/j.jinorgbio.2019.01.020.

[15] M. Zampakou, A. G. Hatzidimitriou, N. Athanasios, G. Psomas, Neutral and cationic manganese(II)- diclofenac complexes: structure and biological evaluation, $J$. Coord. Chem. 68, 4355-4372 (2015). DOI:10.1080/00958972.2015.1098633.

[16] J. I. Johnsen, M. Lindskog, F. Ponthan, I. Pettersen, NSAIDs in neuroblastoma therapy, Cancer Lett. 228 , 195-201 (2005). DOI:10.1016/j.canlet.2005.01.058.

[17] P. N. P. Rao, E. E. Knaus, T. P. Road, L. Jolla, Evolution of nonsteroidal anti-inflammatory cyclooxygenase (COX) inhibition and beyond drugs (NSAIDs):, J. Pharm. Sci. 11, 81-110 (2008)

[18] R. Basha, S. Ahmad, S. Safe, J. L. Abbruzzese, Therapeutic applications of NSAIDS in cancer: Special emphasis on tolfenamic acid, Front. Biosci. 3, 797-805 (2011).

[19] L. Gasparini, E. Ongini, G. Wenk, Non-steroidal antiinflammatory drugs (NSAIDs) in Alzheimer's disease: old and new mechanisms of action, J. Neurochem. 91, 521-536 (2004).

DOI:10.1111/j.1471-4159.2004.02743.x.

[20] W. K. K. Wu, J. J. Yiu Sung, C. W. Lee, J. Yu, C. H. Cho, Cyclooxygenase-2 in tumorigenesis of gastrointestinal cancers: An update on the molecular mechanisms, Cancer Lett. 295, 7-16 (2010). DOI:10.1016/j.canlet.2010.03.015.

[21] K. Schrör, Pharmacology and cellular/molecular mechanisms of action of aspirin and non-aspirin NSAIDs in colorectal cancer, Best Pract. Res. Clin. Gastroenterol. 25, 473-484 (2011). DOI:10.1016/j.bpg.2011.10.016.

[22] A. Tarushi, Z. Kara, J. Kljun, I. Turel, G. Psomas, A. N. Papadopoulos, D. P. Kessissoglou, Antioxidant capacity and DNA-interaction studies of zinc complexes with a non-steroidal anti-inflammatory drug, mefenamic acid, J. Inorg. Biochem, 128, 85-96 (2013). DOI:10.1016/j.jinorgbio.2013.07.013.

[23] P. Tsiliki, F. Perdih, I. Turel, G. Psomas, Structure, DNA- and albumin-binding of the manganese(II) complex with the non-steroidal antiinflammatory drug niflumic acid, Polyhedron, 53, 215-222 (2013). DOI:10.1016/j.poly.2013.01.049.

[24] T. Palacios-hernández, H. Höp, J. L. Sánchez-salas, E. González-Vergara, A. Pérez-Benítez, In vitro antibacterial activity of meclofenamate metal complexes with $\mathrm{Cd}(\mathrm{II})$, $\mathrm{Pb}$ (II), $\mathrm{Co}(\mathrm{II})$, and $\mathrm{Cu}(\mathrm{II})$. [Cd( $\left.\left.\mathrm{C}_{14} \mathrm{H}_{10} \mathrm{NO}_{2} \mathrm{Cl}_{2}\right)_{2} \cdot\left(\mathrm{CH}_{3} \mathrm{OH}\right)\right]_{\mathrm{n}}$ and $\left[\mathrm{Cu}\left(\mathrm{C}_{14} \mathrm{H}_{10} \mathrm{NO}_{2} \mathrm{Cl}_{2}\right)_{2}\left(\mathrm{C}_{5} \mathrm{H}_{5} \mathrm{~N}\right)_{2}\right]$. J. Inorg. Biochem, 139, 85-92 (2014). DOI:10.1016/j.jinorgbio.2014.06.008.

[25] Y. C. Chu, T. T. Wang, L. J. Wang, Q. Y. Luo, R. Jia, T. C. Hong, X. M. Wang, H. L. Zhu, Synthesis, characterization, and biological evaluation of a novel $\mathrm{Zn}(\mathrm{II})$ naproxen complex, Polyhedron. 163, 71-76 (2019). DOI:10.1016/j.poly.2019.01.040.

[26] A. A. Khandar, Z. Mirzaei-Kalar, N. Shahabadi, S. Hadidi, H. Abolhasani, S. A. Hosseini-Yazdi, A. Jouyban, Antimicrobial, cytotoxicity, molecular modeling and
DNA cleavage/binding studies of zinc-naproxen complex: switching DNA binding mode of naproxen by coordination to zinc ion, J. Biomol. Struct. Dyn. 1-13 (2020). DOI:10.1080/07391102.2020.1854858.

[27] B. Tang, J. Wang, Q. Wang, Y. Xiao, Y. Huang, X. Liao, H. Li, Calcium(II)-naproxen complex: Synthesis, characterization, and interaction with human serum albumin, Spectrosc. Lett. 49, 404-412 (2016). DOI: https://doi.org/10.1080/00387010.2016.1174137.

[28] M. Zampakou, N. Rizeq, V. Tangoulis, A. N. Papadopoulos, F. Perdih, I. Turel, G. Psomas, Manganese(II) complexes with the non-steroidal antiinflammatory drug tolfenamic acid: Structure and biological perspectives, Inorg. Chem. 53, 2040-2052 (2014). DOI:10.1021/ic4025487.

[29] M. S. Hasan, N. Das, A detailed in vitro study of naproxen metal complexes in quest of new therapeutic possibilities, Alexandria J. Med., 53, 157-165 (2017). DOI:10.1016/j.ajme.2016.06.003.

[30] S. Hasan, N. Das, Z. Al Mahmud, S. M. A. Rahman, Pharmacological evaluation of naproxen metal complexes on antinociceptive, anxiolytic, CNS depressant, and hypoglycemic properties, $A d v$ Pharmacol Sci., 2016, 1-7 (2016). DOI:10.1155/2016/3040724.

[31] S. Hasan, R. Kayesh, F. Begum, S. M. A. Rahman, Transition metal complexes of naproxen: synthesis, characterization, forced degradation studies, and analytical method verification, J Anal Methods Chem. 2016, 1-10 (2016). DOI:10.1155/2016/3560695.

[32] M. Akter, S. K. Saha, S. M. A. Rahman, Gastroenterohistopathology studies of synthesized naproxen esters in young healthy Sprague-Dawley Rat Model, J. Pharm. Sci .2, 49-53 (2015).

[33] A.Szorcsik, L. Nagy, J. Sletten, G. Szalontai, E. Kamu, T. Fiore, L. Pellerito, E. Kalman Preparation and structural studies on dibutyltin(IV) complexes with pyridine mono- and dicarboxylic acids, J. Org. Chem. 689, 1145-1154 (2004).

DOI: 10.1016/j.jorganchem.2003.11.040.

[34] A. Altay, H. Tohma, L. Durmaz, Preliminary phytochemical analysis and evaluation of in vitro antioxidant, antiproliferative, antidiabetic, and anticholinergics effects of endemic Gypsophila taxa from Turkey, J. Food Biochem. 43, 1-11 (2019). DOI:10.1111/jfbc.12908.

[35] İ. Yapıcı, A. Altay, B. Öztürk Sarıkaya, M. Korkmaz, A. Atila, İ. Gülçin, E. Köksal, In vitro antioxidant and cytotoxic activities of extracts of endemic tanacetum erzincanense together with phenolic content by LC-ESIQTOF-MS, Chem. Biodivers., 18 (2021). DOI:10.1002/cbdv.202000812.

[36] A. Altay, S. Celep, A. E. Yaprak, I. Baskose, F. Bozoglu, Glassworts as Possible anticancer agents against human colorectal adenocarcinoma cells with their nutritive, antioxidant and phytochemical profiles, Chem. Biodivers., 14, (2017). DOI:10.1002/cbdv.201600290.

[37] N. Miura, Y. Shinohara, Cytotoxic effect and apoptosis induction by silver nanoparticles in HeLa cells, Biochem. Biophys. Res. Commun. 390, 733-737 (2009). DOI:10.1016/j.bbrc.2009.10.039. 
[38] C. N. Banti, S. K. Hadjikakou, Non-steroidal antiinflammatory drugs (NSAIDs) in metal complexes and their effect at the cellular level, Eur. J. Inorg. Chem. 2016, 3048-3071 (2016). DOI:10.1002/ejic.201501480.

[39] X. Totta, A. A. Papadopoulou, A. G. Hatzidimitriou, A. Papadopoulos, G. Psomas, Synthesis, structure and biological activity of nickel(II) complexes with mefenamato and nitrogen-donor ligands, J. Inorg. Biochem. 145, 79-93 (2015).

DOI:10.1016/j.jinorgbio.2015.01.009.doi:10.1016/j.jinor gbio.2015.01.009.

[40] L. Giovagnini, C. Marzano, F. Bettio, D. Fregona, Mixed complexes of $\mathrm{Pt}(\mathrm{II})$ and $\mathrm{Pd}(\mathrm{II})$ with ethylsarcosinedithiocarbamate and 2-/3-picoline as antitumor agents, J. Inorg. Biochem. 99, 2139-2150 (2005). DOI:10.1016/j.jinorgbio.2005.07.016.

[41] A. Altay, S. Caglar, B. Caglar, Z. S. Sahin, Novel silver(I) complexes bearing mefenamic acid and pyridine derivatives: Synthesis, chemical characterization and in vitro anticancer evaluation, Inorganica Chim. Acta. 493, 61-71 (2019). DOI:10.1016/j.ica.2019.05.008.

[42] A. Altay, S. Caglar, B. Caglar, O. Sahin, Synthesis, structural, thermal elucidation and in vitro anticancer activity of novel silver(I) complexes with non-steroidal anti-inflammatory drugs diclofenac and mefenamic acid including picoline derivatives, Polyhedron, 151, 160 170 (2018). DOI:10.1016/j.poly.2018.05.038.

[43] B. Harurluoglu, A. Altay, S. Caglar, E. Kubra, K. Yeniceri, B. Caglar, Z. S. S, Binuclear silver(I) complexes with the non-steroidal anti-inflammatory drug tolfenamic acid: Synthesis, characterization, cytotoxic activity and evaluation of cellular mechanism of action, Polyhedron, 202 (2021). DOI:10.1016/j.poly.2021.115189.

[44] A. Altay, S. Caglar, B. Caglar, Silver(I) complexes containing diclofenac and niflumic acid induce apoptosis in human-derived cancer cell lines, Arch. Physiol. Biochem., 1-11 (2019).

DOI:10.1080/13813455.2019.1662454.

[45] S. Caglar, A. Altay, In vitro anticancer activity of novel $\mathrm{Co}(\mathrm{II})$ and $\mathrm{Ni}$ (II) complexes of non-steroidal anti- inflammatory drug niflumic acid against human breast adenocarcinoma MCF-7 Cells, Cell Biochem. Biophys. (2021). DOI:10.1007/s12013-021-00984-z.

[46] D. Mahendiran, R. S. Kumar, A. K. Rahiman, Heteroleptic silver(I) complexes with $2,2^{\prime}: 6^{\prime}, 2^{\prime \prime}$-terpyridines and naproxen: DNA interaction, EGFR/VEGFR2 kinase, growth inhibition and cell cycle arrest studies, Mater. Sci. Eng. C. 76, 601-615 (2017). DOI:10.1016/j.msec.2017.03.085.

[47] S. Bharathi, D. Mahendiran, R. S. Kumar, H. J. Choi, M Gajendiran, K. Kim, A. K. Rahiman, Silver(I) metallodrugs of thiosemicarbazones and naproxen: biocompatibility, in vitro anti-proliferative activity and in silico interaction studies with EGFR, VEGFR2 and LOX receptors, Toxicol. Res. 9, 28-44 (2020). DOI:10.1093/TOXRES/TFAA001.

[48] J. Chang, G. Wang, Nonsteroidal anti-inflammatory drug effects on osteoblastic cell cycle, cytotoxicity, and cell death, Connect. Tissue Res. 46, 200-210 (2005). DOI: $10.1080 / 03008200500344025$.

[49] V. Erfani-Moghadam, M. Aghaei, A. Soltani, A. Ravaghi, M. Cordani, S. Shirvani, S. Moazen, H. Balakheyli, ST8 micellar/niosomal vesicular nanoformulation for delivery of naproxen in cancer cells: Physicochemical characterization and cytotoxicity evaluation, J. Mol. Struct. 1211 (2020). DOI:10.1016/j.molstruc.2020.127867.

[50] M. Ramar, B. Manikandan, P. N. Marimuthu, T. Raman, A. Mahalingam, P. Subramanian, S. Karthick, A. Munusamy, Synthesis of silver nanoparticles using Solanum trilobatum fruits extract and its antibacterial, cytotoxic activity against human breast cancer cell line MCF 7, Spectrochim. Acta - Part A Mol. Biomol. Spectrosc. 140 223-228 (2015). DOI:10.1016/j.saa.2014.12.060.

[51] K. Kawata, M. Osawa, S. Okabe, In vitro toxicity of silver nanoparticles at noncytotoxic doses to HepG2 human hepatoma cells, Environ. Sci. Technol. 43, 60466051 (2009). DOI:10.1021/es900754q. 